\title{
Studies on the Constituents of Cimicifuga Species. XIX.1) Eight New Glycosides from Cimicifuga simplex WORMSK.
}

\author{
Akiko Kusano, ${ }^{a}$ Makio Shibano, ${ }^{a}$ Genjiro Kusano, ${ }^{*, a}$ and Toshio Miyase ${ }^{b}$ \\ Osaka University of Pharmaceutical Sciences, ${ }^{a}$ 4-20-1 Nasahara, Takatsuki, Osaka 569-11, Japan and School of \\ Pharmaceutical Sciences, University of Shizuoka, ${ }^{b}$ Yada, 52-1, Shizuoka 422, Japan. \\ Received May 7, 1996; accepted July 13, 1996
}

Eight new glycosides were isolated from Cimicifuga simplex (Ranunculaceae), and their structures were determined to be 23-O-acetyl-7,8-didehydroshengmanol-3- $O$ - $\alpha$-L-arabinopyranoside (1), 24-epi-24-O-acetyl-7,8didehydrohydroshengmanol-3- $O$ - $\beta$-D-galactopyranoside (2), 7,8-didehydrocimigenol-3- $O$ - $\beta$-D-galactopyranoside (3), 24-epi-24- $O$-acetylhydroshengmanol-3- $O$ - $\beta$-D-galactopyranoside (4), cimigenol-3- $O$ - $\beta$-D-galactopyranoside (5), 25$O$-methylcimigenol-3-O- $\beta$-D-galactopyranoside (6), 25- $O$-acetylcimigenol-3- $O$ - $\beta$-D-galactopyranoside (7) and 25 $O$-acetylcimigenol-3- $O$ - $\beta$-D-glucopyranoside (8). Genuine aglycones were obtained by the hydrolysis of $1-7$ with lactase F[Amano] and of 8 with cellulase T[Amano]4. Acerinol was prepared from 7,8-didehydrocimigenol and showed antilipemic effects. effect

Key words Cimicifuga simplex; cycloartane glycoside; 7,8-didehydrocycloartane glycoside; lactase; cellulase; antilipemic

We recently reported on the isolation of four new triterpenic xylosides from the aerial parts of Cimicifuga simplex. ${ }^{1)}$ In our continuing work, we isolated eight new glycosides (1-8) from the same herb. This paper deals with the isolation and structural elucidation of these glycosides (1-8), along with conversion to 7,8-didehydrocimigenol (1b), acerinol (1c), 24-epi-didehydrocimigenol (2b), 24-epi-acerinol (2c) and cimigol (4b) from the aglycones $(\mathbf{1 a}, \mathbf{2 a}, \mathbf{4 a})$ and the antilipemic effects as biological properties of acerinol (1c).

Glycosides 1-8 were obtained as described in the experimental section by repeated chromatographies on silica gel $\left(\mathrm{SiO}_{2}\right)$, octadecylsilanized silicic acid (ODS) columns, HPLC and preparative TLC (pTLC) of the methanol extract of the underground parts and the aerial parts of the title plant.

Glycoside 1 was obtained from the underground parts as colorless needles, $\mathrm{mp} 239-240^{\circ} \mathrm{C},[\alpha]_{\mathrm{D}}-55.5^{\circ}$, and the molecular formula was determined to be $\mathrm{C}_{37} \mathrm{H}_{56} \mathrm{O}_{10}$ on the basis of positive high resolution secondary ion mass spectroscopy (pos. HR-SI-MS) and the data of the ${ }^{13} \mathrm{C}$ NMR spectrum. The IR spectrum showed strong hydroxyl bands and an acetyl band. The ${ }^{1} \mathrm{H}$ - and ${ }^{13} \mathrm{C}$-NMR signals were assigned using ${ }^{1} \mathrm{H}-{ }^{1} \mathrm{H}$ shift correlation spectroscopy $\left({ }^{1} \mathrm{H}-{ }^{1} \mathrm{H}\right.$ COSY $)$ and ${ }^{13} \mathrm{C}-{ }^{1} \mathrm{H}$ COSY, and heteronuclear multiple bond correlation (HMBC) spectra as shown in Tables 1 and 2. The spectra of 1 showed the presence of 23-acetoxy and 24,25-epoxy groups on a side chain of a cycloartane derivative ${ }^{2-4)}\left(23-\mathrm{H}, 24-\mathrm{H}, \mathrm{CH}_{3} \mathrm{CO}, \mathrm{C}-23\right.$, $\mathrm{C}-24, \mathrm{C}-25, \mathrm{C}-26, \mathrm{C}-27)$, and also a $7(8)$-double bond on a cycloartane nucleus ${ }^{5)}\left(7-\mathrm{H}, 19-\mathrm{H}_{2}, \mathrm{C}-7, \mathrm{C}-8, \mathrm{C}-19\right)$.

Treatment of 1 with lactase $\mathrm{F}$ [Amano] provided a genuine aglycone, 1a, mp $89-90^{\circ} \mathrm{C}, \mathrm{C}_{32} \mathrm{H}_{48} \mathrm{O}_{6},[\alpha]_{\mathrm{D}}$ $-75.2^{\circ}$, which was formulated as $(23 R, 24 S)$-23-acetoxy24,25-epoxy-9,19-cyclolanost-7-en-16-one-3 $\beta, 15 \alpha$-diol named 23- $O$-acetyl-7,8-didehydroshengmanol, as shown in Fig. 1. This formulation was certificated as follows: The molecular formula was clarified by pos. HR-SI-MS. The circular dichroism (CD) of 1 showed a strong negative Cotton effect $\left([\theta]_{317}-9.77 \times 10^{3}\right)$, clarifying the presence

* To whom correspondence should be addressed. of a 16-keto group on a cycloartane skeleton. ${ }^{2)}$ 1a was converted to 7,8-didehydro cimigenol (1b), which was identified by comparison of the spectral data with the reported data, $\left.{ }^{6}\right)$ on $1 \% \mathrm{Na}_{2} \mathrm{CO}_{3}$ treatment followed by $5 \% \mathrm{AcOH}$ treatment as shown in Fig. 2. This conversion suggested the presence of a 16-keto group and the stereochemistry of the $23 R$ and $24 S$ configurations in 1 and 1a.

Reflux of $1 \mathrm{~b}$ in $50 \%$ AcOH provided acerinol (1c), certifying that $1,1 \mathrm{a}$ and $\mathbf{1 b}$ have a 9,19-cyclolanost-7-en$3 \beta$-ol system. ${ }^{5}$ The stereochemistry of 15 -hydroxy and a secondary methyl group (C-21) has not been reported in acerinol (1c), ${ }^{7)}$ but by the nuclear Overhauser effect (NOE) between $18-\mathrm{H}_{3}$ and $15 \beta-\mathrm{H}$, and $21-\mathrm{H}_{3}$ and $17 \alpha-\mathrm{H}$ in the rotating frame nuclear Overhauser effect spectroscopy (ROESY) spectrum of 1c, 15 $\alpha$-hydroxy (15R) and $20 R$ configurations were established at this time, as shown in Fig. 2.

The ${ }^{1} \mathrm{H}-\mathrm{NMR}$ spectrum of 1 showed the presence of an $\alpha$-L-arabinopyranosyl group. Acidic hydrolysis of $\mathbf{1}$ provided $\mathrm{L}$-arabinose, $[\alpha]_{\mathrm{D}}+73.5^{\circ}$, as identified by TLC and HPLC. The ${ }^{13} \mathrm{C}$-NMR spectrum of 1 showed that C-3 appeared at $\delta 88.19$ by a glycosylation shift of $10.46 \mathrm{ppm}$ from that of 1a. Thus, 1 should be formulated as $23-O$-acetyl-7,8-didehydroshengmanol-3-O- $\alpha$-L-arabinopyranoside, as shown in Fig. 1.

Glycosides 2-5 were obtained from the $n$ - $\mathrm{BuOH}$ fraction and glycosides $6-\mathbf{8}$ from the aqueous fraction of $\mathrm{MeOH}$ extracts of the aerial parts by treatments similar to 1.

Glycoside 2 was obtained as colorless needles, $\mathrm{mp}$ $243-244^{\circ} \mathrm{C},[\alpha]_{\mathrm{D}}-11.4^{\circ}$, and the molecular formula was determined to be $\mathrm{C}_{38} \mathrm{H}_{60} \mathrm{O}_{12}$ by both pos. HR-SI-MS and the data of the ${ }^{13} \mathrm{C}-\mathrm{NMR}$ spectrum. The IR spectrum showed strong hydroxyl bands and an acetyl band. The ${ }^{1} \mathrm{H}$ - and ${ }^{13} \mathrm{C}$-NMR signals were assigned as with 1 and are summarized in Tables 1 and 2.

Treatment of 2 with lactase $\mathrm{F}$ [Amano] provided a genuine aglycone $2 \mathrm{a}, \mathrm{mp} 229-230^{\circ} \mathrm{C},[\alpha]_{\mathrm{D}}-18.5^{\circ}$, $\mathrm{C}_{32} \mathrm{H}_{50} \mathrm{O}_{7}$, which was formulated as $24-\mathrm{O}$-acetyl-7,8(C) 1996 Pharmaceutical Society of Japan 
Table 1. ${ }^{1} \mathrm{H}-\mathrm{NMR}$ Data of New Glycosides and New Aglycones

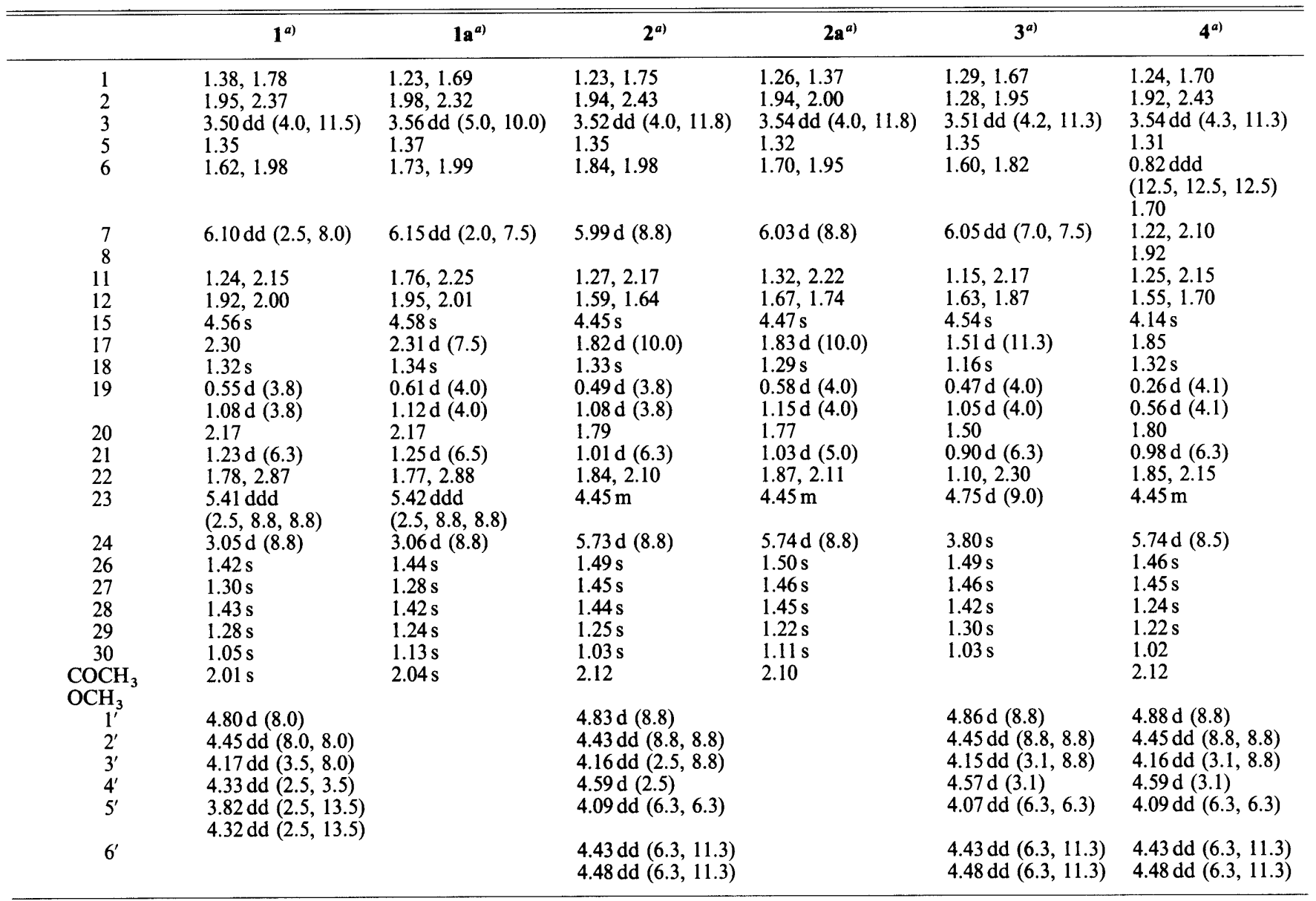

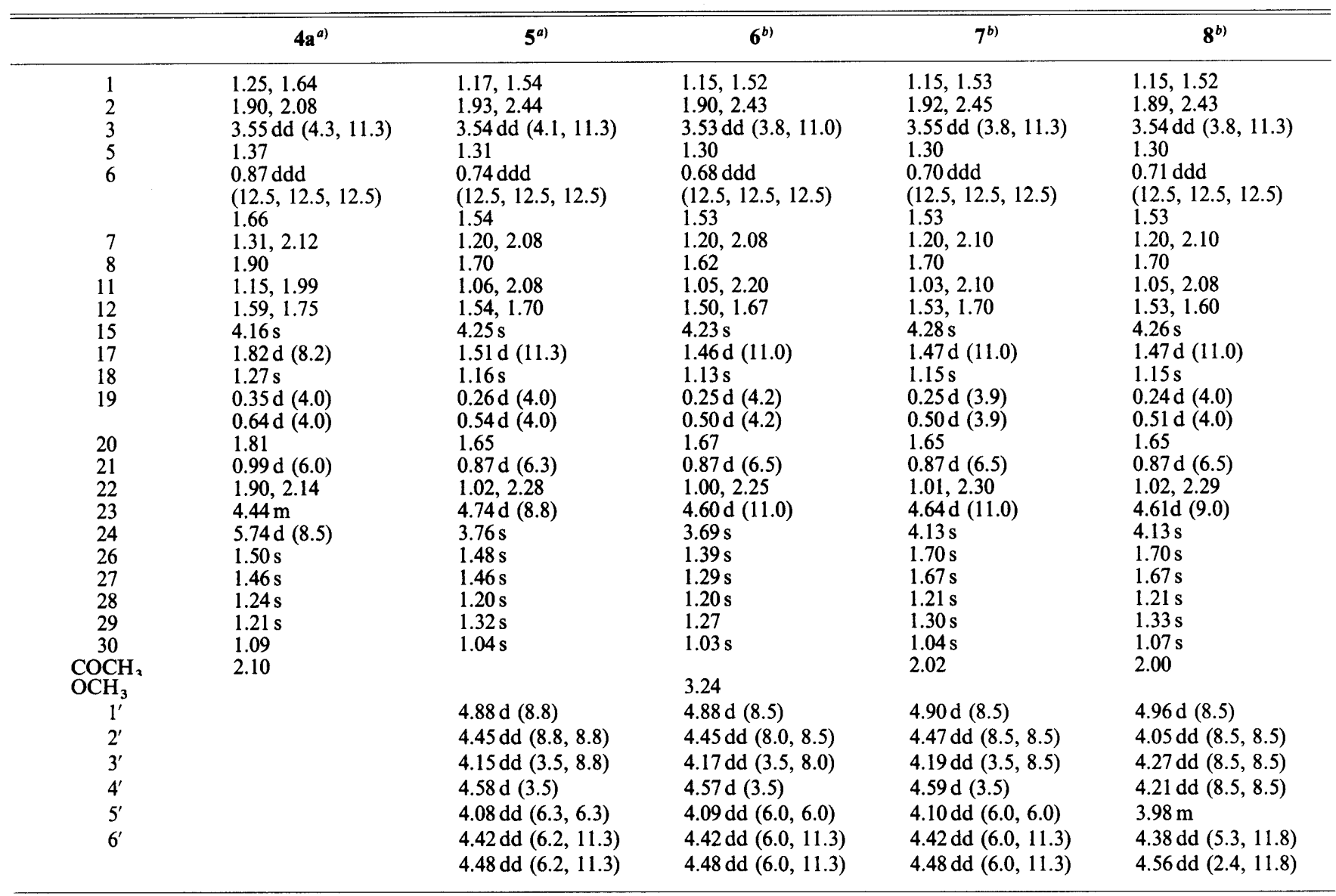


Table 2. ${ }^{13} \mathrm{C}-\mathrm{NMR}$ Data of New Glycosides and New Aglycones

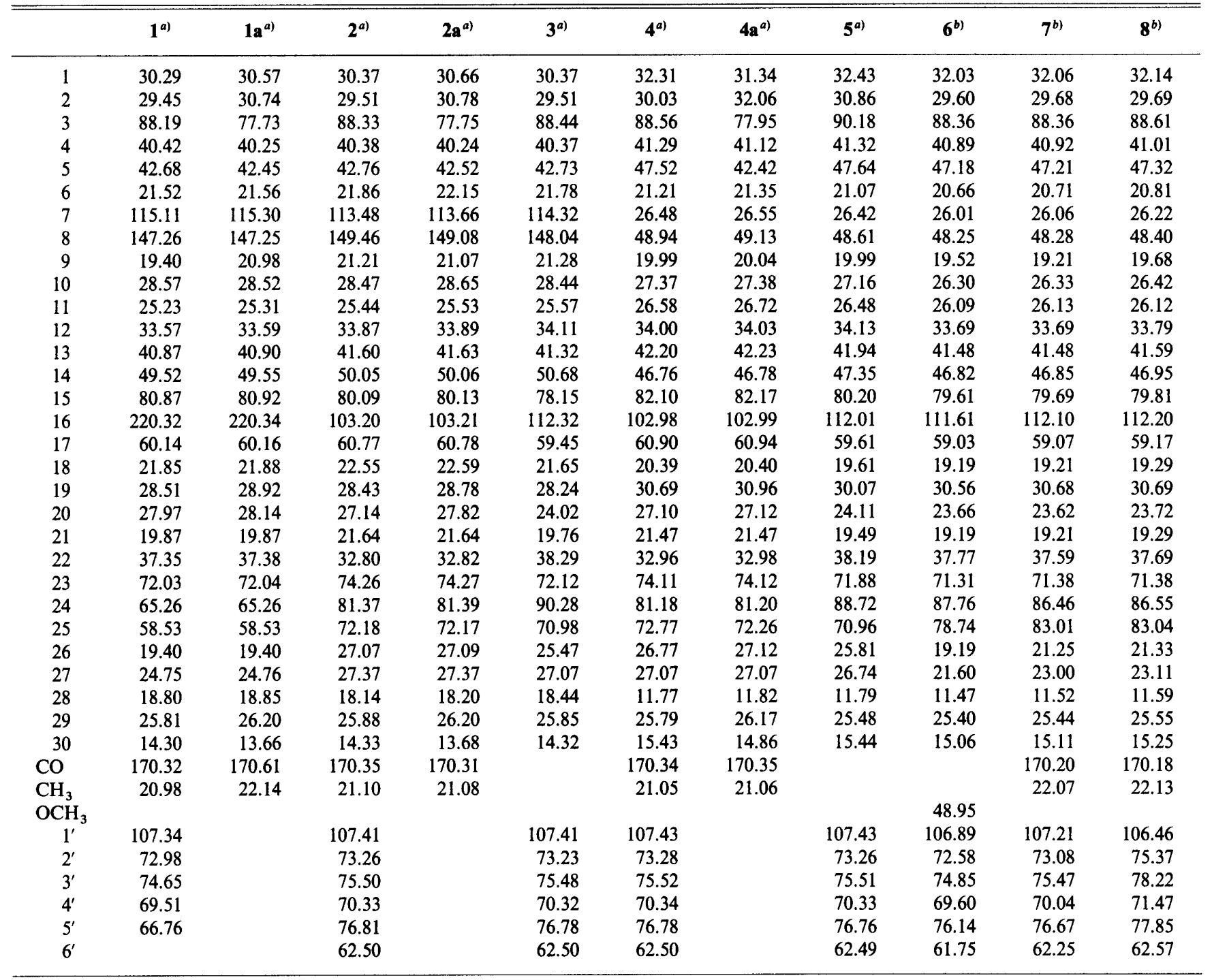

a) Measured at $100 \mathrm{MHz}$; b) at $75.4 \mathrm{MHz}$.

didehydrohydroshengmanol as follows. The molecular formula was certificated by pos. HR-SI-MS. The IR spectrum showed broad hydroxyl bands and an acetyl band. ${ }^{1} \mathrm{H}$ - and ${ }^{13} \mathrm{C}$-NMR signals of $2 \mathrm{a}$ showed the presence of 24-O-acetoxy-16,23-epoxy-15,16-diol and 7(8)-ene groups on a cycloartane skelton $\left(7-\mathrm{H}, 19-\mathrm{H}_{2}, 15-\mathrm{H}, 23-\mathrm{H}\right.$, 24-H, $\left.\mathrm{CH}_{3} \mathrm{CO}, \mathrm{C}-7, \mathrm{C}-8, \mathrm{C}-19, \mathrm{C}-15, \mathrm{C}-16, \mathrm{C}-23, \mathrm{C}-24\right)$. 2a was treated with $1 \% \mathrm{Na}_{2} \mathrm{CO}_{3}$, followed by acidification with $50 \%$ acetic acid to afford a desacetyl dehydrate (2b), $\mathrm{mp} 236-237^{\circ} \mathrm{C},[\alpha]_{\mathrm{D}}+6.0^{\circ}, \mathrm{C}_{30} \mathrm{H}_{46} \mathrm{O}_{5}$, which was identified as 24-epi-7,8-didehydrocimigenol. $\left.{ }^{6}\right)$ Heating $\mathbf{2 b}$ in dioxane-AcOH $(1: 1)$ provided 24 -epi-acerinol $\left.(2 \mathrm{c}){ }^{6,8}\right)$ The conversion from $2 \mathbf{a}$ to $2 \mathbf{b}$, and then to $2 \mathbf{c}$, suggested the presence of $3 \beta$-hydroxy-7,8-didehydro-9,19-cyclolanostane and $(23 R, 24 R)$-24-acetoxy-16-hydroxy-16,23epoxy moieties.

The CD spectrum of a 2a-shift reagent adduct $\left(\mathrm{CCl}_{4}\right)$ showed a strong positive Cotton effect $\left([\theta]_{313}+8.9 \times 10^{4}\right)$ and a negative Cotton effect $\left([\theta]_{285}-7.3 \times 10^{4}\right)$, certificating the presence of $15 \alpha, 16 \alpha$-dihydroxy groups on a cycloartane nucleus. $\left.{ }^{9}\right)$ Thus, 2 a should be formulated as $(23 R, 24 R)$-24-acetoxy-16,23-epoxy-9,19-cyclolanost-7-en-
$3 \beta, 15 \alpha, 16 \alpha$-triol, named 24-epi-24-O-acetyl-7,8-didehydrohydroshengmanol.

The ${ }^{1} \mathrm{H}-\mathrm{NMR}$ spectrum of $\mathbf{2}$ showed the presence of a $\beta$-D-galactopyranosyl group. Acidic hydrolysis of 2 gave D-galactose, $[\alpha]_{\mathrm{D}}+44.6^{\circ}$, as identified by TLC and HPLC. The ${ }^{13} \mathrm{C}$-NMR spectrum of 2 showed that $\mathrm{C}-3$ appeared at $\delta 88.33$ by a glycosylation shift of $10.58 \mathrm{ppm}$ from that of 2a. Thus, 2 should be formulated as 24-epi-24-O-acetyl7,8-didehydrohydroshengmanol-3-O- $\beta$-D-galactopyranoside, as shown in Fig. 1. Galactosides 3-7 were also formulated as 3-O- $\beta$-D-galactopyranosides, as in 2.

Glycoside 3 was obtained as colorless needles, mp $>300^{\circ} \mathrm{C},[\alpha]_{\mathrm{D}}-9.2^{\circ}$, and the molecular formula was determined to be $\mathrm{C}_{36} \mathrm{H}_{56} \mathrm{O}_{10}$ by pos. HR-SI-MS and the data of the ${ }^{13} \mathrm{C}$-NMR spectrum. The IR spectrum showed strong hydroxyl bands. The ${ }^{1} \mathrm{H}$ - and ${ }^{13} \mathrm{C}-\mathrm{NMR}$ signals were assigned as in $\mathbf{1}$ and are summarized in Tables 1 and 2.

Enzymatic hydrolysis of $\mathbf{3}$ provided a genuine aglycone 1b, mp $227-228^{\circ} \mathrm{C},[\alpha]_{\mathrm{D}} 0^{\circ},[\alpha]_{450}-8.7^{\circ},[\alpha]_{400}-21.7^{\circ}$, $[\alpha]_{300}-160.8^{\circ}, \mathrm{C}_{30} \mathrm{H}_{46} \mathrm{O}_{5}$, which was identified to $7,8-$ didehydrocimigenol by comparison of the spectral data 

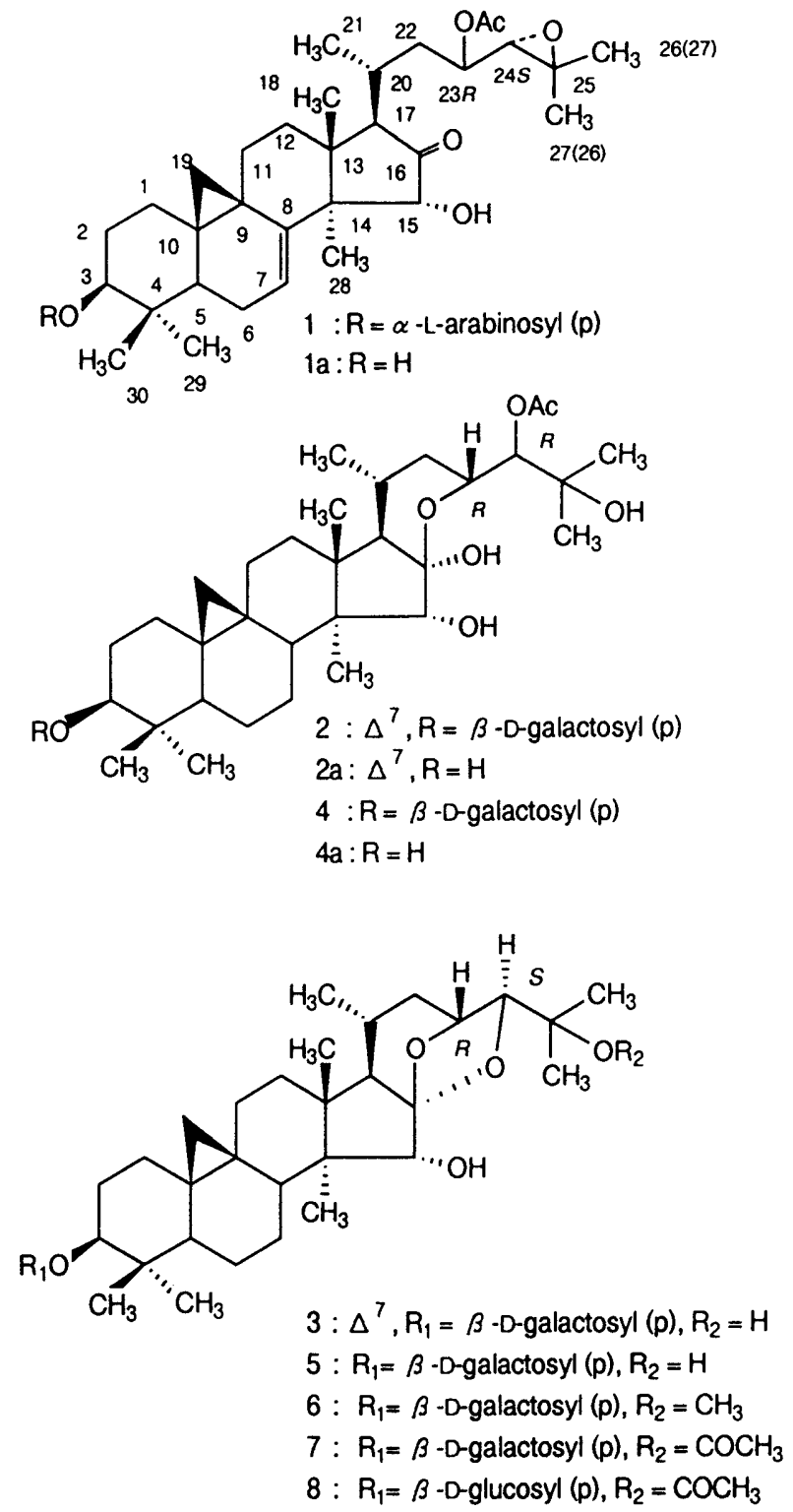

Fig. 1. Structures of New Glycosides and New Aglycones

with those of reported data ${ }^{6}{ }^{6}$ D-Galactose was identified by acidic hydrolysis of 3 . Thus, 3 should be formulated as 7,8-didehydrocimigenol-3- $O-\beta$-D-galactopyranoside, as shown in Fig. 1.

Glycoside 4 was obtained as an inseparable mixture with $2(2: 4=1: 5)$, and the molecular formula was determined to be $\mathrm{C}_{38} \mathrm{H}_{62} \mathrm{O}_{12}$ by pos. HR-SI-MS and the data of the ${ }^{13} \mathrm{C}$-NMR spectrum. The ${ }^{1} \mathrm{H}$ - and ${ }^{13} \mathrm{C}$-NMR signals were assigned as in $\mathbf{1}$ and are summarized in Tables 1 and 2.

Enzymatic hydrolysis of $\mathbf{4}$ provided a genuine aglycone 4a, mp 194- $195^{\circ} \mathrm{C},[\alpha]_{\mathrm{D}}+16.2^{\circ}, \mathrm{C}_{32} \mathrm{H}_{52} \mathrm{O}_{7}$, which was supposed to be a 7,8-dihydro derivative of $2 \mathrm{a}$, named 24-epi-24-O-acetylhydroshengmanol, as follows. The molecular formula was certificated by the pos. HR-SI-MS. The IR spectrum showed broad hydroxyl bands and an acetyl band. The $\mathrm{CD}$ of a $4 \mathrm{a}$-shift reagent adduct $\left(\mathrm{CCl}_{4}\right)$ showed a strong positive Cotton effect $\left([\theta]_{313}+7.4 \times 10^{4}\right)$ and a negative Cotton effect $\left([\theta]_{287}-6.6 \times 10^{4}\right)$, certificating the presence of $15 \alpha, 16 \alpha$-dihydroxy groups on a cycloartane nucleus. ${ }^{9)}$ 4a was transferred to cimigol $(4 \mathrm{~b}),{ }^{10)}$ by deacetylation with $1 \% \mathrm{Na}_{2} \mathrm{CO}_{3}$, followed by reflux in dioxane-AcOH $(1: 1)$, suggesting the presence of a $(23 R, 24 R)$-24- $O$-acety-16-hydroxy-16,23-epoxy moiety in $4 a$. The stereochemistry of a $15 \beta$-hydroxy group has been reported in cimigol, ${ }^{10}$ ) but by observation of a NOE between $18-\mathrm{H}_{3}$ and $15 \beta-\mathrm{H}$ in a ROESY spectrum of $4 \mathrm{~b}$, the 15-hydroxy group was revised to an $\alpha$ orientation at this time, as shown in $\mathbf{4 b}$.

The high resolution ${ }^{1} \mathrm{H}$-NMR spectra of the samples of cimigol, its diacetate and its diketone used before for the structural elucidation showed a contamination of the 7-ene congeners $(\mathrm{ca} .20 \%)$ at this time. It seems that the preparation of the diacetates and diketo derivatives from a mixture of cimigol and its 7-ene congener and the purification of their 24,25-dehydrates by chromatographies should have led to a wrong conclusion of a $15 \beta$-hydroxy group in cimigol at that time.

D-Galactose was identified by the acidic hydrolysis of 4, as in 2. Thus, 4 should be formulated as 24-epi-24-Oacetylhydroshengmanol-3- $O-\beta$-D-galactopyranoside, as shown in Fig. 1.

Glycoside 5 was obtained as colorless needles, mp $229-230^{\circ} \mathrm{C},[\alpha]_{\mathrm{D}}+22.9^{\circ}$, and the molecular formula was determined to be $\mathrm{C}_{36} \mathrm{H}_{58} \mathrm{O}_{10}$ by pos. HR-SI-MS and the data of the ${ }^{13} \mathrm{C}-\mathrm{NMR}$ spectrum. The IR spectrum showed strong hydroxyl bands at $3600-3200 \mathrm{~cm}^{-1}$. The ${ }^{1} \mathrm{H}$ - and ${ }^{13} \mathrm{C}-\mathrm{NMR}$ signals are summarized in Tables 1 and 2.

An aglycone 5a, mp $233-234^{\circ} \mathrm{C},[\alpha]_{\mathrm{D}}+38.2^{\circ}$, $\mathrm{C}_{30} \mathrm{H}_{48} \mathrm{O}_{5}$ was obtained by hydrolysis of 5 with lactase $\mathrm{F}$ [Amano] and was identified as cimigeno ${ }^{11)}$ by direct comparison of TLC, IR and ${ }^{1} \mathrm{H}-\mathrm{NMR}$ spectra with those of an authentic specimen. D-Galactose was identified by the acidic hydrolysis of 5 , as in 2 . Thus, 5 should be formulated as cimigenol-3-O- $\beta$-D-galactopyranoside, as shown in Fig. 1.

Glycoside 6 was obtained as colorless needles, mp $209-210^{\circ} \mathrm{C},[\alpha]_{\mathrm{D}}+20.4^{\circ}$, and the molecular formula was determined to be $\mathrm{C}_{37} \mathrm{H}_{60} \mathrm{O}_{10}$ by pos. HR-SI-MS and the data of the ${ }^{13} \mathrm{C}$-NMR spectrum. The IR spectrum showed strong hydroxyl bands. The ${ }^{1} \mathrm{H}$ - and ${ }^{13} \mathrm{C}-\mathrm{NMR}$ signals are summarized in Tables 1 and 2. The spectra of 6 were partially similar to those of 5 except for an additional signal due to a methoxy group. An aglycone $6 \mathrm{a}, \mathrm{mp}$ $241-242^{\circ} \mathrm{C},[\alpha]_{D}+38.2^{\circ}, \mathrm{C}_{31} \mathrm{H}_{50} \mathrm{O}_{5}$ was obtained by the hydrolysis of 6 with lactase $F[$ Amano] as in 2, and it was identified to 25- $O$-methylcimigenol by direct comparison of the TLC, IR and ${ }^{1} \mathrm{H}-\mathrm{NMR}$ spectra with those of an authentic specimen. ${ }^{3,12)} \mathrm{D}$-Galactose was identified by the acidic hydrolysis of 6 . Thus, 6 should be formulated as $25-O$-methylcimigenol-3- $O-\beta$-D-galactopyranoside, as shown in Fig. 1.

Glycoside 7 was obtained as colorless needles, $\mathrm{mp}$ $213-214^{\circ} \mathrm{C},[\alpha]_{\mathrm{D}}+18.7^{\circ}$, and the molecular formula was determined to be $\mathrm{C}_{38} \mathrm{H}_{60} \mathrm{O}_{11}$ by pos. HR-SI-MS and the data of the ${ }^{13} \mathrm{C}$-NMR spectrum. The IR spectrum showed strong hydroxyl bands and an acetyl band. The ${ }^{1} \mathrm{H}-$ and ${ }^{13} \mathrm{C}$-NMR signals are summarized in Tables 1 and 2 . The spectra of 7 were similar to those of 6, except for a signal due to an acetoxy group in spite of a methoxy group.

An aglycone $7 \mathrm{a}, \mathrm{mp} 191-192^{\circ} \mathrm{C},[\alpha]_{\mathrm{D}}+34.1^{\circ}$, $\mathrm{C}_{32} \mathrm{H}_{50} \mathrm{O}_{6}$, was obtained by the hydrolysis of 7 with lactase F[Amano], and was identified as 25-O-acetyl cimigenol 


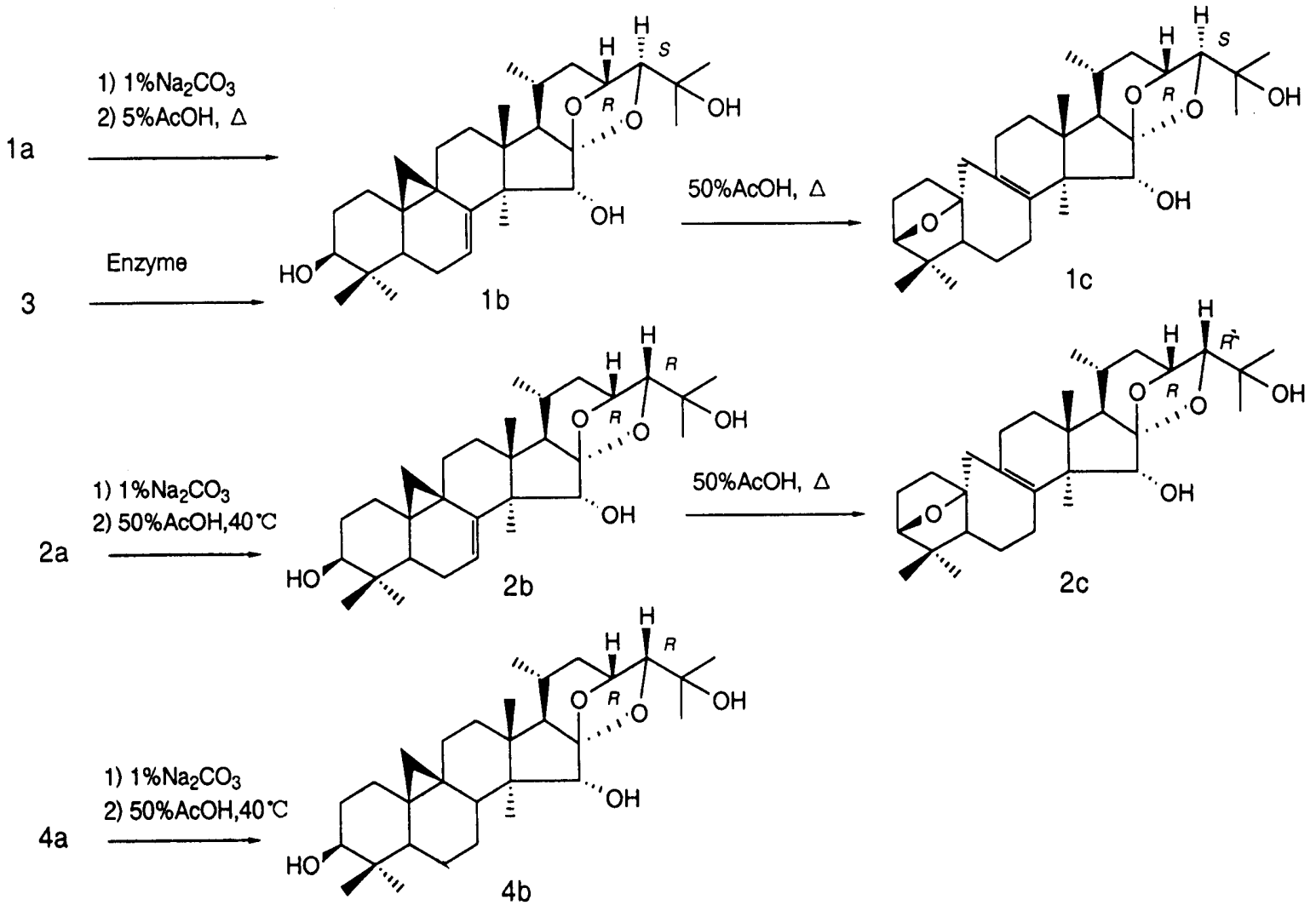

Fig. 2. Chemical Conversion of New Genuine Aglycones

by direct comparison of TLC, IR and ${ }^{1} \mathrm{H}-\mathrm{NMR}$ spectra with those of an authentic specimen. ${ }^{13,14)} \mathrm{D}$-Galactose was identified by acidic hydrolysis of 7 , as with 2 . Thus, 7 should be formulated as $25-O$-acetylcimigenol-3- $O-\beta$-Dgalactopyranoside, as shown in Fig. 1.

Glycoside 8 was obtained as colorless needles, $\mathrm{mp}$ $216-217^{\circ} \mathrm{C},[\alpha]_{\mathrm{D}}+20.6^{\circ}$, and the molecular formula was determined to be $\mathrm{C}_{38} \mathrm{H}_{60} \mathrm{O}_{11}$ by both pos. HR-SI-MS and the data of the ${ }^{13} \mathrm{C}$-NMR spectrum. The IR spectrum showed strong hydroxyl bands and an acetyl band. The ${ }^{1} \mathrm{H}$ - and ${ }^{13} \mathrm{C}$-NMR signals are summarized in Tables 1 and 2. The spectra of $\mathbf{8}$ were similar to those of 7 , except for the signals due to the 3-O- $\beta$-D-glucopyranosyl group, in spite of those of the 3-O- $\beta$-D-galactopyranosyl group. ${ }^{14)}$ 25-O-Acetylcimigenol (7a) was obtained by hydrolysis of 8 with cellulase T[Amano]4 and was identified by the direct comparison of TLC, IR and ${ }^{1} \mathrm{H}-\mathrm{NMR}$ spectra with those of an authentic specimen. ${ }^{13,14)}$ D-Glucose was identified by the acidic hydrolysis of 8 as with the previous report. ${ }^{15)}$ Thus, 8 should be formulated as $25-O$ acetylcimigenol-3- $O-\beta$-D-glucopyranoside, as shown in Fig. 1.

All of the ${ }^{1} \mathrm{H}$ - and ${ }^{13} \mathrm{C}$-NMR signals of acerinol (1c) and 24-epi-acerinol $(2 \mathrm{c})$ were assigned using the data of ${ }^{1} \mathrm{H}-{ }^{1} \mathrm{H}$ COSY, ${ }^{13} \mathrm{C}-{ }^{1} \mathrm{H}$ COSY, HMBC and ROESY spectra and are summarized in Table 3. Drastic changes in the structures in the conversion of 7,8-didehydrocimigenol (1b) and 24-epi-7,8-didehydrocimigenol (2b) to acerinol (1c) and 24-epi-acerinol (2c) partially produced a large migration of signals, and several signals of $2 \mathrm{c}$ have been assigned differently from the reported data. ${ }^{6}$ )

Acerinol (1c) was subjected to 61 items of biological assay by Pan. Lab. (Tai-wan), because of the interesting
Table 3. ${ }^{1} \mathrm{H}$ - and ${ }^{13} \mathrm{C}-\mathrm{NMR}$ Data of $1 \mathrm{c}$ and $2 \mathrm{c}$

\begin{tabular}{|c|c|c|c|c|c|}
\hline & 1c & $2 c$ & & 1c & $2 c$ \\
\hline C-1 & 36.74 & 36.74 & $1-\mathrm{H}$ & $1.50,1.68$ & $1.43,1.63$ \\
\hline $\mathrm{C}-2$ & 25.43 & 25.88 & $2-\mathrm{H}$ & $1.67,1.87$ & $1.66,1.86$ \\
\hline C-3 & 84.89 & 84.87 & $3-\mathrm{H}$ & $3.73 \mathrm{~d}(5.0)$ & $3.72 \mathrm{~d}(5.0)$ \\
\hline C-4 & 45.29 & 45.29 & $5-\mathrm{H}$ & 1.26 & $1.26 \mathrm{~d}(11.3)$ \\
\hline C-5 & 55.15 & 55.15 & $6-\mathrm{H}$ & $1.46,1.90$ & $1.45,1.86$ \\
\hline C-6 & 32.56 & 32.20 & $7-\mathrm{H}$ & $2.08,2.58$ & $2.07,2.59$ \\
\hline C-7 & 31.26 & 31.30 & & & \\
\hline C-8 & 137.37 & 137.69 & & & \\
\hline C-9 & 123.98 & 123.48 & & & \\
\hline C- 10 & 90.14 & 89.84 & & & \\
\hline C-11 & 31.08 & 31.19 & $11-\mathrm{H}$ & $2.04,2.88$ & $2.04,2.89$ \\
\hline C- 12 & 23.27 & 23.22 & $12-\mathrm{H}$ & $1.63,1.75$ & $1.42,1.49$ \\
\hline C-13 & 41.44 & 41.29 & $15-\mathrm{H}$ & $4.44 \mathrm{~s}$ & $4.41 \mathrm{~s}$ \\
\hline C-14 & 49.72 & 49.89 & $17-\mathrm{H}$ & 1.45 & 1.71 \\
\hline$C-15$ & 75.48 & 75.96 & $18-\mathrm{H}$ & 0.97 & 1.00 \\
\hline C-16 & 112.32 & 112.53 & $19-\mathrm{H}$ & $1.83 \mathrm{~d}(13.8)$ & $1.81 \mathrm{~d}(13.8)$ \\
\hline $\mathrm{C}-17$ & 57.73 & 58.98 & & $3.27 \mathrm{~d}(13.8)$ & $3.27 \mathrm{~d}(13.8)$ \\
\hline C-18 & 17.44 & 17.37 & $20-\mathrm{H}$ & 1.70 & 1.72 \\
\hline C-19 & 36.28 & 36.27 & & & \\
\hline $\mathrm{C}-20$ & 24.30 & 23.53 & & & \\
\hline $\mathrm{C}-21$ & 20.26 & 20.12 & $21-\mathrm{H}$ & $0.89 \mathrm{~d}(8.0)$ & $0.99 \mathrm{~d}(6.3)$ \\
\hline C-22 & 38.10 & 29.69 & $22-\mathrm{H}$ & $1.04,2.28$ & $1.96,2.64$ \\
\hline C-23 & 72.14 & 73.94 & $23-\mathrm{H}$ & $4.76 \mathrm{~d}(8.8)$ & 4.60 \\
\hline C-24 & 89.81 & 84.06 & $24-\mathrm{H}$ & $3.77 \mathrm{~s}$ & $3.70 \mathrm{~d}(4.5)$ \\
\hline C-25 & 70.88 & 68.57 & $26-\mathrm{H}$ & 1.47 & 1.39 \\
\hline C-26 & 27.18 & 30.67 & $27-\mathrm{H}$ & 1.45 & 1.26 \\
\hline C-27 & 25.88 & 25.97 & $28-\mathrm{H}$ & 1.22 & 1.14 \\
\hline C- 28 & 17.51 & 17.52 & $29-\mathrm{H}$ & 0.91 & 0.91 \\
\hline C- 29 & 24.94 & 24.96 & $30-\mathrm{H}$ & 0.96 & 0.96 \\
\hline C-30 & 23.52 & 23.76 & & & \\
\hline
\end{tabular}

structure of a modified polyoxygenated triterpene, and only antilipemic effects were positive in hyperlipemic mice induced by injection (i.v.) of a surfactant, Triton WR-1339. 
Therefore, a similar experiment was carried out and the results are shown in the experimental section. Clofibrate $(300 \mathrm{mg} / \mathrm{ml})$ showed $37 \%$ plasma triglycerides and $77 \%$ plasma cholesterol level to the control, while $1 \mathrm{c}(100 \mathrm{mg} /$ $\mathrm{ml})$ and $(200 \mathrm{mg} / \mathrm{ml})$ showed $1.4 \%$ and $1.5 \%$ triglycerides, and a $31 \%$ and $37 \%$ cholesterol level, respectively. It is interesting that 1c has stronger antilipemic effects than clofibrate. These antilipemic effects were found neither in normal mice nor in spontanously diabetic mice. ${ }^{16)}$ A study for clarifying the mechanisms of the antilipemic effects with acerinol (1c) against hyperlipemic mice induced by Triton will be continued.

\section{Experimental}

General The instruments used in this work were as follows: a Yanagimoto micromelting apparatus (for melting points, uncorrected); a JASCO digital polarimeter (for specific rotation, measured at $20^{\circ} \mathrm{C}$ ), a JASCO ORD/UV-5 and a JASCO J-20A spectrometer (for ORD and $\mathrm{CD}$, measured at $20^{\circ} \mathrm{C}$ ); a Perkin-Elmer 1720X-FT IR spectrometer (for IR spectra); a Hitachi M-80 spectrometer (for MS spectra); and a Varian Gemini-200, a Varian XL-300 and a JEOL $\alpha-400$ (for NMR spectra, measured in pyridine- $d_{5}$ solution containing a few drops of $\mathrm{D}_{2} \mathrm{O}$, on the $\delta$ scale using tetramethylsilane as an internal standard). Column chromatography was carried out on silica gel (Wakogel C-200) and ODS-A YMC. HPLC was conducted on a Gilson 305 pump equipped with a JASCO 830-RI as a detector and a JASCO Model 800 . Silica gel $60 \mathrm{~F}_{254}$ (Merck) precoated TLC plates were used, and detection was carried out by $40 \% \mathrm{H}_{2} \mathrm{SO}_{4}$ followed by heating.

Isolation of 1 The dried underground parts $(100 \mathrm{~g})$ of Cimicifuga simplex grown in the experimental station for medical plant studies, Faculty of Pharmaceutical Sciences, Tohoku University, were extracted with methanol $(200 \mathrm{ml} \times 3)$ under reflux for $2 \mathrm{~h}$ each. After evaporation in vacuo, the extract $(11.0 \mathrm{~g})$ was partitioned between $n$-BuOH-EtOAc $(50: 50)$ and water three times. The soluble fraction to the organic solvents $(4.4 \mathrm{~g})$ was chromatographed on silica gel $(120 \mathrm{~g}, 3 \mathrm{~cm} \times 33 \mathrm{~cm})$. After elution with $\mathrm{CHCl}_{3}(80 \mathrm{ml} \times 8)$ and $\mathrm{CHCl}_{3}-\mathrm{MeOH}(20: 1)(80 \mathrm{ml} \times 6)$, fractions $(450 \mathrm{mg})$ eluted with $\mathrm{CHCl}_{3}-\mathrm{MeOH}(20: 1)(80 \mathrm{ml} \times 3)$ were rechromatographed on ODS $(80 \mathrm{~g}, 3.0 \times 20 \mathrm{~cm})$ and eluted with $\mathrm{MeOH}-\mathrm{H}_{2} \mathrm{O}(2: 1)$, then $\mathrm{MeOH}-\mathrm{H}_{2} \mathrm{O}(4: 1)$. The latter fraction was subjected to pTLC [solvent: $\mathrm{CHCl}_{3}-\mathrm{MeOH}(5: 1)$ ] and HPLC [column: Cosmosil 10 ph $(10 \mu \mathrm{m}$, i.d. $4.6 \times 250 \mathrm{~mm})$; solvent: $\mathrm{MeOH}-\mathrm{H}_{2} \mathrm{O}$ $\mathrm{CH}_{3} \mathrm{CN}(10: 10: 3)$; column temperature: $40^{\circ} \mathrm{C}$; effluent speed: $1 \mathrm{ml} / \mathrm{min}$ ]. Recrystallization of the fraction at $t_{\mathrm{R}} 10 \mathrm{~min}$ from $\mathrm{MeOH}$ provided glycoside $1(45 \mathrm{mg})$ as colorless needles, $\mathrm{mp} 239-240^{\circ} \mathrm{C},[\alpha]_{\mathrm{D}}-55.5$, $\mathrm{C}_{37} \mathrm{H}_{56} \mathrm{O}_{10}$. Pos. HR-SI-MS: $m / z 661.3948\left[(\mathrm{M}+\mathrm{H})^{+}\right]$, error \pm 0 , pos. SI-MS: $m / z 661\left[(\mathrm{M}+\mathrm{H})^{+}\right], m / z 683\left[(\mathrm{M}+\mathrm{Na})^{+}\right]$. IR $(\mathrm{KBr}) \mathrm{cm}^{-1}$ : $3600-3300(\mathrm{OH}), 1738$ (acetyl group). CD: $[\theta]_{317}-9.77 \times 10^{3}$ $\left(c=1 \times 10^{-4}, \mathrm{MeOH}\right){ }^{1} \mathrm{H}$ - and ${ }^{13} \mathrm{C}-\mathrm{NMR}$ : Tables 1,2 .

Isolation of 2-6 After the elution of $7 \beta$-hydroxy-23-O-acetylshengmanol xyloside in the chromatography of the $n-\mathrm{BuOH}$ fraction from $\mathrm{MeOH}$ extracts of the aerial parts of Cimicifuga simplex $(6.1 \mathrm{~kg})$, the adsorbed materials were eluted with $\mathrm{CHCl}_{3}-\mathrm{MeOH}(5: 1)$ as in the previous report. ${ }^{3)}$ The eluates were rechromatographed on ODS $(100 \mathrm{~g}$, i.d. $3.2 \times 24 \mathrm{~cm})$. Fractions eluted with $\mathrm{MeOH}-\mathrm{H}_{2} \mathrm{O}(3: 1)$ were subjected to HPLC [column: CrestPak C18T-5 (5 $\mu$ m, i.d. $4.6 \times 250 \mathrm{~mm})$; solvent: $\mathrm{MeOH}-\mathrm{H}_{2} \mathrm{O}-\mathrm{CH}_{3} \mathrm{CN}$ (10:11:3); effluent speed: $1 \mathrm{ml} / \mathrm{min}$; column temperature, $40^{\circ} \mathrm{C}$ ] to afford mixtures of $2-4$ and $3-5$. The former mixture was separated into each by HPLC using YMC C8 $(5 \mu \mathrm{m}$, i.d. $20 \times 250 \mathrm{~mm}$ ) as a column and $\mathrm{MeOH}-\mathrm{H}_{2} \mathrm{O}(70: 30)$ as a solvent. Recrystallization from $\mathrm{MeOH}$ provided 2 as colorless needles $(35 \mathrm{mg})$, while 4 was a mixture with $2[4: 2(5: 1)](15 \mathrm{mg})$. The latter mixture was subjected to HPLC using Develosil PhA-T-5 $(5 \mu \mathrm{m}, 20 \times 250 \mathrm{~mm})$ as a column, and $\mathrm{CH}_{3} \mathrm{CN}-\mathrm{H}_{2} \mathrm{O}(35: 65)$ as a solvent to afford 3 and 5 . Recrystallization from $\mathrm{MeOH}$ provided $3(10 \mathrm{mg})$ as colorless needles and $5(7 \mathrm{mg})$ as colorless needles.

Glycoside 2: Colorless needles, $\mathrm{mp} 243-244^{\circ} \mathrm{C},[\alpha]_{\mathrm{D}}-11.4^{\circ}(c=1.1$, $\mathrm{MeOH}), \mathrm{C}_{38} \mathrm{H}_{60} \mathrm{O}_{12}$. Pos. HR-SI-MS: $m / z 691.4037\left[(\mathrm{M}-\mathrm{OH})^{+}\right]$, error: -1.7 (m mass). Pos. SI-MS: $m / z 691\left[(\mathrm{M}-\mathrm{OH})^{+}\right]$. IR $(\mathrm{KBr}) \mathrm{cm}^{-1}$ : $3650-3200(\mathrm{OH}), 1718\left(\mathrm{CH}_{3} \mathrm{CO}\right) .{ }^{1} \mathrm{H}-$ and ${ }^{13} \mathrm{C}-\mathrm{NMR}$ (pyridine- $\left.d_{5}\right) \delta$ : Tables 1,2

Glycoside 3: Colorless needles, $\mathrm{mp}>300^{\circ} \mathrm{C},[\alpha]_{\mathrm{D}}-9.2^{\circ}(c=0.9$,
$\mathrm{MeOH}) . \mathrm{C}_{36} \mathrm{H}_{56} \mathrm{O}_{10}$. Pos. HR-SI-MS: $m / z 649.3944\left[(\mathrm{M}+\mathrm{H})^{+}\right]$, error: -0.4 (m mass), pos. SI-MS: $m / z 649\left[(\mathrm{M}+\mathrm{H})^{+}\right]$. IR $(\mathrm{KBr}) \mathrm{cm}^{-1}$ : $3600-3200(\mathrm{OH}) .{ }^{1} \mathrm{H}$ - and ${ }^{13} \mathrm{C}-\mathrm{NMR}$ (pyridine- $d_{5}$ ) $\delta$ : Tables $1,2$.

Glycoside 4: $\mathrm{C}_{38} \mathrm{H}_{62} \mathrm{O}_{12}$. Pos. HR-SI-MS: $m / z 733.4126\left[(\mathrm{M}+\mathrm{Na})^{+}\right]$, error: -1.0 (m mass). Pos. SI-MS: $m / z 733\left[(\mathrm{M}+\mathrm{Na})^{+}\right] .{ }^{1} \mathrm{H}-$ and ${ }^{13} \mathrm{C}$-NMR (pyridine- $d_{5}$ ) $\delta$ : Tables $1,2$.

Glycoside 5: Colorless powder, $\mathrm{mp} 229-230^{\circ} \mathrm{C},[\alpha]_{\mathrm{D}}+22.9^{\circ}(c=0.6$, $\mathrm{MeOH}), \mathrm{C}_{36} \mathrm{H}_{58} \mathrm{O}_{10}$. Pos. HR-SI-MS: $m / z 651.4112\left[(\mathrm{M}+\mathrm{H})^{+}\right]$, error: +0.7 (m mass). Pos. SI-MS: $m / z 651\left[(\mathrm{M}+\mathrm{H})^{+}\right]$. IR $(\mathrm{KBr}) \mathrm{cm}^{-1}$ : $3600-3200(\mathrm{OH}) .{ }^{1} \mathrm{H}$ - and ${ }^{13} \mathrm{C}-\mathrm{NMR}$ (pyridine- $d_{5}$ ) $\delta$ : Tables $1,2$.

Isolation of $6-8$ The crystalline precipitates $(3 \mathrm{~g})$ from the aqueous fraction after removal of the $n$-BuOH fraction from $\mathrm{MeOH}$ extracts of the aerial parts of Cimicifuga simplex $(6.1 \mathrm{~kg})$ were chromatographed on $\mathrm{SiO}_{2}[150 \mathrm{~g}$, i.d. $4.0 \times 30.0 \mathrm{~cm}$, and two diglycosides eluted with $\left.\mathrm{CHCl}_{3}-\mathrm{MeOH}(10: 1-0: 1)\right]$, as in the previous report. ${ }^{14)}$ Fractions eluted with $\mathrm{CHCl}_{3}-\mathrm{MeOH}(5: 1)(228 \mathrm{mg})$ were rechromatographed on ODS $(100 \mathrm{~g}$, i.d. $3.2 \times 24 \mathrm{~cm})$. Fractions eluted with $\mathrm{MeOH}$ were subjected to HPLC [column: Cosmosil $10 \mathrm{ph}(10 \mu \mathrm{m}$, i.d. $4.6 \mathrm{~mm} \times 250 \mathrm{~mm})$; solvent: $\mathrm{MeOH}-\mathrm{H}_{2} \mathrm{O}-\mathrm{CH}_{3} \mathrm{CN}(10: 9: 3)$; effluent speed: $1 \mathrm{ml} / \mathrm{min}$; column temperature, $40^{\circ} \mathrm{C}$ ] to afford $6(5.6 \mathrm{mg}), 7(7.7 \mathrm{mg})$ and 8 $(15.8 \mathrm{mg})$ after recrystalization from $\mathrm{MeOH}$.

Glycoside 6: Colorless powder, mp 209-210 ${ }^{\circ} \mathrm{C},[\alpha]_{\mathrm{D}}+20.4^{\circ}(c=0.5$, $\mathrm{MeOH}), \mathrm{C}_{37} \mathrm{H}_{60} \mathrm{O}_{10}$. Pos. HR-SI-MS: $m / z 665.4293\left[(\mathrm{M}+\mathrm{H})^{+}\right]$, error: +3.2 (m mass). Pos. SI-MS: $m / z 665\left[(\mathrm{M}+\mathrm{H})^{+}\right]$. IR $(\mathrm{KBr}) \mathrm{cm}^{-1}$ : $3600-3200(\mathrm{OH}) .{ }^{1} \mathrm{H}$ - and ${ }^{13} \mathrm{C}-\mathrm{NMR}$ (pyridine- $d_{5}$ ) $\delta$ : Tables $1,2$.

Glycoside 7: Colorless powder, mp $213-214^{\circ} \mathrm{C},[\alpha]_{\mathrm{D}}+18.7^{\circ}(c=0.6$, $\mathrm{MeOH}), \mathrm{C}_{38} \mathrm{H}_{60} \mathrm{O}_{11}$. Pos. HR-SI-MS: $m / z 693.4201\left[(\mathrm{M}+\mathrm{H})^{+}\right]$, error: -0.9 (m mass). Pos. SI-MS: $m / z 693\left[(\mathrm{M}+\mathrm{H})^{+}\right]$. IR $(\mathrm{KBr}) \mathrm{cm}^{-1}$ : $3600-3200(\mathrm{OH}), 1739$ (acetyl). ${ }^{1} \mathrm{H}-$ and ${ }^{13} \mathrm{C}-\mathrm{NMR}$ (pyridine- $d_{5}$ ) $\delta$ : Tables 1, 2.

Glycoside 8: Colorless needles, $\mathrm{mp} 216-217^{\circ} \mathrm{C},[\alpha]_{\mathrm{D}}+20.6^{\circ}(c=0.7$, $\mathrm{MeOH}), \mathrm{C}_{38} \mathrm{H}_{60} \mathrm{O}_{11}$. Pos. HR-SI-MS: $m / z$ 693.4199 $\left[(\mathrm{M}+\mathrm{H})^{+}\right]$, error: -1.1 (m mass). Pos. SI-MS: $m / z 693\left[(\mathrm{M}+\mathrm{H})^{+}\right]$. IR (KBr) $\mathrm{cm}^{-1}$ : $3600-3300(\mathrm{OH}), 1737$ (acetyl). ${ }^{1} \mathrm{H}-$ and ${ }^{13} \mathrm{C}-\mathrm{NMR}$ (pyridine- $d_{5}$ ) $\delta$ : Tables 1, 2.

Hydrolysis of 1-7 with Lactase F[Amano] $1(13.2 \mathrm{mg})$ was dissolved in $1 \%$ ethanolic $\mathrm{AcOH}(20 \mathrm{ml})$, then water $(40 \mathrm{ml})$ was added with stirring and the solution was adjusted to $\mathrm{pH} 4.5$ by the dropwise addition of AcOH. Lactase F[Amano] (from Aspergillus oizae, $200 \mathrm{mg}$ ) was added. The solution was stirred for $2 \mathrm{~d}$ at $25^{\circ} \mathrm{C}$. Then, the reaction solution was shaken with EtOAc $(30 \mathrm{ml} \times 3)$, and after washing the joined EtOAc layer with water and drying it over $\mathrm{Na}_{2} \mathrm{SO}_{4}$, the solvent was evaporated in vacuo. The residue was chromatographed on $\mathrm{SiO}_{2}(12 \mathrm{~g})$ and eluted with $n$-hexane-EtOAc $(1: 1)$ to afford $1 \mathrm{a}$ as colorless needles $(4.0 \mathrm{mg})$ after purification with HPLC and recrystallization from $\mathrm{MeOH}$. Similar treatments of $2(26.5 \mathrm{mg})$, a mixture $(27.5 \mathrm{mg})$ of 3 and $5(3: 2)$, a mixture $(13.0 \mathrm{mg})$ of 2 and $4(1: 5)$ and a mixture $(18.0 \mathrm{mg})$ of 6 and $7(2: 1)$ provided $2 \mathrm{a}(13.5 \mathrm{mg}), 1 \mathrm{~b}(5.4 \mathrm{mg}), 4 \mathrm{a}(5.0 \mathrm{mg}), 5 \mathrm{a}(6.1 \mathrm{mg}), 6 \mathrm{a}(3.8 \mathrm{mg})$ and $7 \mathrm{a}(2.0 \mathrm{mg})$ as aglycones.

1a: $\mathrm{mp} 89-90^{\circ} \mathrm{C},[\alpha]_{\mathrm{D}}-75.2^{\circ}(c=0.29, \mathrm{MeOH}), \mathrm{C}_{32} \mathrm{H}_{48} \mathrm{O}_{6}$. Pos. HR-SI-MS: $m / z 529.3514\left[(\mathrm{M}+\mathrm{H})^{+}\right]$, error: -0.3 (m mass). Pos. SI-MS: $m / z 529\left[(\mathrm{M}+\mathrm{H})^{+}\right]$. IR $\left(\mathrm{CHCl}_{3}\right) \mathrm{cm}^{-1}: 3600-3300(\mathrm{OH}), 1737$ (acetyl). ${ }^{1} \mathrm{H}$ - and ${ }^{13} \mathrm{C}-\mathrm{NMR}$ (pyridine- $d_{5}$ ) $\delta$ : Tables $1,2$.

2a: $\mathrm{mp} 229-230^{\circ} \mathrm{C},[\alpha]_{\mathrm{D}}-18.5^{\circ}(c=0.4, \mathrm{MeOH}) . \mathrm{C}_{32} \mathrm{H}_{50} \mathrm{O}_{7}$. Pos. HR-SI-MS: $m / z$ 546.3552 [(M) ${ }^{+}$, error: -0.2 (m mass). Pos. SI-MS: $m / z$ $546\left[(\mathrm{M})^{+}\right], 529\left[(\mathrm{M}-\mathrm{OH})^{+}\right]$. IR $\left(\mathrm{CHCl}_{3}\right) \mathrm{cm}^{-1}: 3600-3250(\mathrm{OH})$, 1744 (acetyl). ${ }^{1} \mathrm{H}$ - and ${ }^{13} \mathrm{C}-\mathrm{NMR}$ (pyridine- $d_{5}$ ) $\delta$ : Tables $1,2 . \mathrm{CD}$ of 2a-Eu(fod $)_{3}:[\theta]_{313}=+8.9 \times 10^{4},[\theta]_{285}=-7.3 \times 10^{4}\left(c=1.1 \times 10^{-7} \mathrm{M}\right.$ of $2 \mathrm{a}, 1.1 \times 10^{-7} \mathrm{M}$ of $\left.\mathrm{Eu}(\mathrm{fod})_{3}, \mathrm{CCl}_{4}\right)$.

lb: $\mathrm{mp} 227-228^{\circ} \mathrm{C},[\alpha]_{\mathrm{D}} \pm 0^{\circ}(c=0.5, \mathrm{MeOH})$. ORD: $[\alpha]_{450}-8.7^{\circ}$, $[\alpha]_{400}-21.7^{\circ},[\alpha]_{300}-160.8^{\circ}(c=0.46, \mathrm{MeOH}) . \mathrm{C}_{30} \mathrm{H}_{46} \mathrm{O}_{5}$. Pos. HR-SI-MS: $m / z$ 487.3423 [(M+H) ${ }^{+}$, error: 0.2 (m mass). Pos. SI-MS: $m / z 487\left[(\mathrm{M}+\mathrm{H})^{+}\right], 509\left[(\mathrm{M}+\mathrm{Na})^{+}\right] . \mathrm{IR}\left(\mathrm{CHCl}_{3}\right) \mathrm{cm}^{-1}: 3500-3200$ $(\mathrm{OH}) .{ }^{1} \mathrm{H}-\mathrm{NMR}$ (pyridine- $d_{5}$ ) $\delta: 3.52$ (dd, $\left.J=4.8,11.0 \mathrm{~Hz}, 3-\mathrm{H}\right), 6.10$ (dd, $J=1.9,7.5 \mathrm{~Hz}, 7-\mathrm{H}), 4.57(\mathrm{~s}, 15-\mathrm{H}), 1.20(\mathrm{~s}, 18-\mathrm{H}), 0.55(\mathrm{~d}, J=4.0 \mathrm{~Hz}$, 19-H), 1.11 (d, $J=4.0 \mathrm{~Hz}, 19-\mathrm{H}), 0.91(\mathrm{~d}, J=6.3 \mathrm{~Hz}, 21-\mathrm{H}), 4.76$ (brd, $J=8.8 \mathrm{~Hz}, 23-\mathrm{H}), 3.80(\mathrm{~s}, 24-\mathrm{H}), 1.50(\mathrm{~s}, 26-\mathrm{H}), 1.47(\mathrm{~s}, 27-\mathrm{H}), 1.43$ (s, 28-H), $1.18(\mathrm{~s}, 29-\mathrm{H}), 1.10(\mathrm{~s}, 30-\mathrm{H}),{ }^{13} \mathrm{C}-\mathrm{NMR}$ (pyridine- $\left.d_{5}\right) \delta: 77.81$ (C-3), 114.47 (C-7), 148.01 (C-8), 78.20 (C-15), 112.32 (C-16), 72.11 (C-23), 90.28 (C-24), $70.97(\mathrm{C}-25)$. ${ }^{1} \mathrm{H}-\mathrm{NMR}\left(\mathrm{CDCl}_{3}\right.$ containing $\left.\mathrm{D}_{2} \mathrm{O}\right)$ $\delta: 3.32(\mathrm{dd}, J=4.0,11.6 \mathrm{~Hz}, 3-\mathrm{H}), 5.63(\mathrm{dd}, J=2.3,6.9 \mathrm{~Hz}, 7-\mathrm{H}), 4.12$ $(\mathrm{s}, 15-\mathrm{H}), 1.03\left(\mathrm{~s}, 18-\mathrm{H}_{3}\right), 0.89\left(\mathrm{~d}, J=6.9 \mathrm{~Hz}, 21-\mathrm{H}_{3}\right), 4.48(\mathrm{brd}, J=9.5 \mathrm{~Hz}$, 23-H), $3.46(\mathrm{~s}, 24-\mathrm{H}), 1.20\left(\mathrm{~s}, 26-\mathrm{H}_{3}\right), 1.20\left(\mathrm{~s}, 27-\mathrm{H}_{3}\right), 1.04\left(\mathrm{~s}, 28-\mathrm{H}_{3}\right)$, $1.00\left(\mathrm{~s}, 29-\mathrm{H}_{3}\right), 0.85\left(\mathrm{~s}, 30-\mathrm{H}_{3}\right) .{ }^{1} \mathrm{H}-\mathrm{NMR}\left(\mathrm{CDCl}_{3}\right)$ data were identical 
to the reported ones of 7,8-didehydrocimigenol. ${ }^{6}$ )

4a: $m p 194-195^{\circ} \mathrm{C},[\alpha]_{\mathrm{D}}+16.2^{\circ}(c=0.5, \mathrm{MeOH}) . \mathrm{C}_{32} \mathrm{H}_{52} \mathrm{O}_{7}$. Pos. HR-SI-MS: $m / z 531.3693$ [(M-OH) ${ }^{+}$, error: 1.0 (m mass). Pos. SI-MS: $m / z 531\left[(\mathrm{M}-\mathrm{OH})^{+}\right], 571\left[(\mathrm{M}+\mathrm{Na})^{+}\right] . \mathrm{IR}\left(\mathrm{CHCl}_{3}\right) \mathrm{cm}^{-1}: 3500-3200$ $(\mathrm{OH}), 1744$ (acetyl). ${ }^{1} \mathrm{H}$ - and ${ }^{13} \mathrm{C}-\mathrm{NMR}$ (pyridine- $d_{5}$ ) $\delta$ : Tables 1,2 . CD of $4 \mathrm{a}-\mathrm{Eu}(\mathrm{fod})_{3}:[\theta]_{313}=+7.4 \times 10^{4},[\theta]_{287}=-6.6 \times 10^{4}\left(c=3.0 \times 10^{-7}\right.$ $\mathrm{M}$ of $4 \mathrm{a}, 3.0 \times 10^{-7} \mathrm{M}$ of $\mathrm{Eu}(\mathrm{fod})_{3}, \mathrm{CCl}_{4}$ ).

5a: $\mathrm{mp} 233-234^{\circ} \mathrm{C}, \mathrm{C}_{30} \mathrm{H}_{48} \mathrm{O}_{5}$. Pos. HR-SI-MS: $m / z 489.3589$ $\left[(\mathrm{M}+\mathrm{H})^{+}\right.$, error: +1.2 (m mass). Pos. SI-MS: $m / z 489\left[(\mathrm{M}+\mathrm{H})^{+}\right]$. IR $\left(\mathrm{CHCl}_{3}\right) \mathrm{cm}^{-1}: 3450-3200(\mathrm{OH})$. The ${ }^{1} \mathrm{H}-\mathrm{NMR}$ spectrum and $R f$ value in TLC were identical to those of cimigenol. ${ }^{9}$

6a: $\operatorname{mp} 241-242^{\circ} \mathrm{C},[\alpha]_{\mathrm{D}}+38.2^{\circ}\left(c=0.25, \mathrm{CHCl}_{3}\right)$. IR $\left(\mathrm{CHCl}_{3}\right) \mathrm{cm}^{-1}$ : $3550-3300(\mathrm{OH})$. The ${ }^{1} \mathrm{H}-\mathrm{NMR}$ spectrum and $R f$ value in TLC were identical to those of 25- $O$-metylcimigenol.

7a: $\mathrm{mp} 191-192^{\circ} \mathrm{C}$. IR $\left(\mathrm{CHCl}_{3}\right) \mathrm{cm}^{-1}: 3550-3300$ (OH), 1725 (acetyl). The ${ }^{1} \mathrm{H}-\mathrm{NMR}$ spectrum and $R f$ value in TLC were identical to those of 25-O-acetylcimigenol.

Hydrolysis of 8 with Cellulase T[Amano]4 $8(7.2 \mathrm{mg})$ was treated similarly to 1-7 with cellulase T[Amano]4 (from Trichoderma viride, $200 \mathrm{mg}$ ), in spite of lactase F[Amano]. 25-O-Acetylcimigenol (8a) was obtained as colorless needles $(4.0 \mathrm{mg})$ by recrystallization from $\mathrm{MeOH}$ and was identified by direct comparison of the ${ }^{1} \mathrm{H}-\mathrm{NMR}$ spectra with an authentic specimen.

Identification of L-Arabinose $1(13 \mathrm{mg})$ was dissolved in $50 \% \mathrm{AcOH}$ solution $(1 \mathrm{ml})$ and refluxed for $3 \mathrm{~h}$. The reaction solution was shaken with EtOAc $(30 \mathrm{ml} \times 3)$, and the water layer was concentrated in vacuo. L-Arabinose, $[\alpha]_{\mathrm{D}}+73.5^{\circ}\left[c=0.2, \mathrm{MeOH}-\mathrm{H}_{2} \mathrm{O}(1: 1)\right]$, was obtained by HPLC [column: LiChrosolb $\mathrm{NH}_{2}(5 \mu \mathrm{m}$, i.d. $4.6 \times 250 \mathrm{~mm})$; solvent: $\mathrm{CH}_{3} \mathrm{CN}-\mathrm{H}_{2} \mathrm{O}(4: 1)$; column temperature: $40^{\circ} \mathrm{C}$; effluent speed: $1 \mathrm{ml} / \mathrm{min}$; $\left.t_{\mathrm{R}} 6.4 \mathrm{~min}\right]$, and it showed the same $R f$ value $(0.51)$ on TLC $\left[n-\mathrm{PrOH}-\mathrm{H}_{2} \mathrm{O}(85: 15)\right]$.

Identification of D-Galactose and D-Glucose $2(10.0 \mathrm{mg})$ was dissolved in $\mathrm{MeOH}(0.7 \mathrm{ml})$, and $1 \mathrm{~N} \mathrm{HCl}(2 \mathrm{ml})$ was added, then the reaction solution was refluxed for $1 \mathrm{~h}$. After being shaken with EtOAc $(30 \mathrm{ml} \times 3)$ to remove the aglycone, the water layer was refluxed again for $1 \mathrm{~h}$ in order to hydrolyze methyl galactosides, and was then subjected to an Amberlite IR-35 column. Elution with water afforded D-galactose $[\alpha]_{\mathrm{D}}$ $+44.6^{\circ}\left[c=0.26, \mathrm{MeOH}-\mathrm{H}_{2} \mathrm{O}(1: 1)\right]$, which was purified by HPLC [the same conditions as above: $\left.t_{\mathrm{R}} 10.2 \mathrm{~min}\right]$ and TLC $[R f: 0.39, n-\mathrm{PrOH}-$ $\left.\mathrm{H}_{2} \mathrm{O}(85: 15)\right]$. D-Galactose was also obtained from a mixture $(3.0 \mathrm{mg})$ of 2 and 4 , one ( $4.3 \mathrm{mg}$ ) of 3 and 5 , one $(3.4 \mathrm{mg}$ ) of 6 and 7 by the same treatment as above and identified by HPLC [column: Shodex RS-Pak DC-613, solvent: $\mathrm{CH}_{3} \mathrm{CN}-\mathrm{H}_{2} \mathrm{O}(4: 1)$, effluent speed: $1 \mathrm{ml} / \mathrm{min}$, column temperature: $70^{\circ} \mathrm{C}$ ] equipped with a chiral detector OR-1: $t_{\mathrm{R}} 23 \mathrm{~min}$, $\alpha_{D}+10-15^{\circ} .{ }^{17)} \mathrm{D}$-Glucose was obtained from $8(3 \mathrm{mg})$ by the same treatment as above and was identified by HPLC (the same conditions) equipped with a chiral detector OR-1: $t_{\mathrm{R}} 20 \mathrm{~min}, \alpha_{\mathrm{D}}+10^{\circ}$

Conversion of $1 \mathrm{a}$ to $1 \mathrm{~b} 1(1.3 \mathrm{mg})$ was dissolved to $\mathrm{MeOH}(1 \mathrm{ml})$, and $2 \% \mathrm{Na}_{2} \mathrm{CO}_{3}(1 \mathrm{ml})$ was added and the solution was stirred at room temperature overnight. The solution neutralized by $5 \% \mathrm{AcOH}$, was shaken with EtOAc $(10 \mathrm{ml} \times 3)$. The residue after removal of the solvent was dissolved to dioxane $(0.5 \mathrm{ml})$ and $5 \% \mathrm{AcOH}(0.5 \mathrm{ml})$ and heated on a boiling water bath for $2 \mathrm{~h}$. After evaporation of the solvents in vacuo, the products were chromatographed on $\mathrm{SiO}_{2}(12 \mathrm{~g})$. The fractions eluted with $n$-hexane-EtOAc $(1: 1)$, which was provided $1 \mathrm{~b}(1.0 \mathrm{mg})$ as colorless needles by recrystallization from EtOAc, which was identified by comparison of the TLC and ${ }^{1} \mathrm{H}-\mathrm{NMR}$ spectrum with those of a genuine aglycone of 3.

Conversion of $1 \mathrm{~b}$ to $1 \mathrm{c} 1 \mathrm{~b}(2.0 \mathrm{mg})$ was dissolved to $\mathrm{MeOH}(1 \mathrm{ml})$ and $\mathrm{AcOH}(1 \mathrm{ml})$ and heated on a boiling water bath for $1 \mathrm{~h}$. The product obtained after the same treatment as above was identified as acerinol (1c) by direct comparison of the ${ }^{1} \mathrm{H}-\mathrm{NMR}$ spectrum and TLC with those of an authentic specimen. ${ }^{1} \mathrm{H}$ - and ${ }^{13} \mathrm{C}-\mathrm{NMR}$ (pyridine- $d_{5}$ ) $\delta$ : Table 3 .

Conversion of $2 \mathrm{a}$ to $2 \mathrm{~b} \quad 2 \mathrm{a}(7.8 \mathrm{mg})$ was stirred in $1 \% \mathrm{Na}_{2} \mathrm{CO}_{3}[\mathrm{MeOH}$ $(2 \mathrm{ml})$ and $\left.2 \% \mathrm{Na}_{2} \mathrm{CO}_{3}(2 \mathrm{ml})\right]$ for $24 \mathrm{~h}$ at room temperature. After neutralization with $5 \% \mathrm{AcOH}$, the mixture was shaken with EtOAc $(20 \mathrm{ml} \times 3)$ and washed with water. The residue after evaporation of the solvent was dissolved in dioxane $(1 \mathrm{ml})$ and $\mathrm{AcOH}(1 \mathrm{ml})$, then warmed at $40^{\circ} \mathrm{C}$ for $1 \mathrm{~h}$. The product was chromatographed on $\mathrm{SiO}_{2}(10 \mathrm{~g})$, eluated with $n$-hexane-EtOAc $(2: 1)$, and purified by HPLC to give $2 \mathbf{b}$, mp $236-237^{\circ} \mathrm{C},[\alpha]_{\mathrm{D}}+6.0^{\circ}(c=0.6, \mathrm{MeOH}) . \mathrm{C}_{30} \mathrm{H}_{46} \mathrm{O}_{5}$, pos. HR-SIMS: $m / z$ 487.3415 $\left[(\mathrm{M}+\mathrm{H})^{+}\right]$, error: $-0.6 \mathrm{~m}$ mass; pos. SI-MS: $m / z$ $487\left[(\mathrm{M}+\mathrm{H})^{+}\right]$. IR $\left(\mathrm{CHCl}_{3}\right) \mathrm{cm}^{-1}: 3550-3200(\mathrm{OH}) .{ }^{1} \mathrm{H}-\mathrm{NMR}$ (pyridine- $d_{5}$ ) $\delta: 3.45(\mathrm{dd}, J=3.1,10.6 \mathrm{~Hz}, 3-\mathrm{H}), 6.12$ (dd, $J=1.5,8.5 \mathrm{~Hz}$,
$7-\mathrm{H}), 4.53(\mathrm{~s}, 15-\mathrm{H}), 1.22\left(\mathrm{~s}, 18-\mathrm{H}_{3}\right), 1.00\left(\mathrm{~d}, J=6.0 \mathrm{~Hz}, 21-\mathrm{H}_{3}\right), 4.62$ (ddd, $J=1.9,4.0,9.8 \mathrm{~Hz}, 23-\mathrm{H}), 3.74(\mathrm{~d}, J=4.0 \mathrm{~Hz}, 24-\mathrm{H}), 1.43\left(\mathrm{~s}, 26-\mathrm{H}_{3}\right)$, $1.29\left(\mathrm{~s}, 27-\mathrm{H}_{3}\right), 1.31\left(\mathrm{~s}, 28-\mathrm{H}_{3}\right), 1.21\left(\mathrm{~s}, 29-\mathrm{H}_{3}\right), 1.12\left(\mathrm{~s}, 30-\mathrm{H}_{3}\right) .{ }^{13} \mathrm{C}-\mathrm{NMR}$ (pyridine- $d_{5}$ ) $\delta: 78.68$ (C-3), 114.50 (C-7), 148.13 (C-8), 78.20 (C-15), 112.32 (C-16), 73.90 (C-23), 84.13 (C-24), 68.64 (C-25). ${ }^{1} \mathrm{H}-\mathrm{NMR}$ (CDCl ${ }_{3}$ containing $\left.\mathrm{D}_{2} \mathrm{O}\right) \delta: 3.33(\mathrm{dd}, J=4.0,11.6 \mathrm{~Hz}, 3-\mathrm{H}), 5.62(\mathrm{dd}, J=2.3$, $7.4 \mathrm{~Hz}, 7-\mathrm{H}), 4.04(\mathrm{~s}, 15-\mathrm{H}), 1.02\left(\mathrm{~s}, 18-\mathrm{H}_{3}\right), 0.91\left(\mathrm{~d}, J=6.9 \mathrm{~Hz}, 21-\mathrm{H}_{3}\right)$, 4.44 (ddd, $J=2.3,4.5,10.2 \mathrm{~Hz}, 23-\mathrm{H}), 3.58$ (d, $J=4.0 \mathrm{~Hz}, 24-\mathrm{H}$ ), 1.24 $\left(\mathrm{s}, 26-\mathrm{H}_{3}\right), 1.33\left(\mathrm{~s}, 27-\mathrm{H}_{3}\right), 1.07\left(\mathrm{~s}, 28-\mathrm{H}_{3}\right), 1.00\left(\mathrm{~s}, 29-\mathrm{H}_{3}\right), 0.87\left(\mathrm{~s}, 30-\mathrm{H}_{3}\right)$. ROESY (pyridine- $d_{5}$ ): NOE between $18-\mathrm{H}_{3}(\delta 1.22)$ and $15 \beta-\mathrm{H}(\delta 4.53)$ $(15 \alpha-\mathrm{OH})$. The above physical data and ${ }^{1} \mathrm{H}-\mathrm{NMR}\left(\mathrm{CDCl}_{3}\right)$ data were identical with the reported ones of 24-epi-7,8-didehydrocimigenol.

Conversion of $2 \mathrm{~b}$ to $2 \mathrm{c} 2 \mathrm{~b}(3.0 \mathrm{mg})$ was treated as in the conversion of $1 \mathrm{~b}$ to $1 \mathrm{c}$ to provide $2 \mathrm{c}$ as colorless needles $(2.5 \mathrm{mg}), \mathrm{mp} 212-213^{\circ} \mathrm{C}$, $[\alpha]_{\mathrm{D}}+59.3^{\circ}(c=1.0, \mathrm{MeOH}) . \mathrm{C}_{30} \mathrm{H}_{46} \mathrm{O}_{5}$. EI-MS: $m / z 486\left[(\mathrm{M})^{+}\right]$. CI-MS: $487\left[(\mathrm{M}+\mathrm{H})^{+}\right]$. ${ }^{1} \mathrm{H}$ - and ${ }^{13} \mathrm{C}-\mathrm{NMR}$ (pyridine- $\left.d_{5}\right) \delta$ : Table 3 . These data were identical with the reported ones of 24-epi-acerinol, ${ }^{3}$ ) except the assignment of some ${ }^{1} \mathrm{H}$ - and ${ }^{13} \mathrm{C}$-NMR signals $\left(\mathrm{CDCl}_{3}\right)$. ROESY: NOEs between $18-\mathrm{H}_{3}$ and $15 \beta-\mathrm{H}, 21-\mathrm{H}_{3}$ and $17 \alpha-\mathrm{H}$, and $28-\mathrm{H}_{3}$ and $17 \alpha-\mathrm{H}$.

Conversion of $4 \mathrm{a}$ to $4 \mathrm{~b} 4 \mathrm{a}(1.5 \mathrm{mg})$ was treated as in the conversion of $1 \mathrm{a}$ to $1 \mathrm{~b}$ to provide $4 \mathrm{~b}$ as colorless needles $(1.0 \mathrm{mg}), \mathrm{mp} 277-278^{\circ} \mathrm{C}$. TLC (Rf: $0.5, n$-hexane-EtOAc $(1: 1)$ and ${ }^{1} \mathrm{H}$-NMR (pyridine- $d_{5}$ ) spectrum were identical with those of an authentic specimen of cimigol. ROESY: NOEs between $18-\mathrm{H}_{3}(\delta 1.22)$ and $15 \beta-\mathrm{H}(\delta 4.25), 18-\mathrm{H}_{3}$ and $20-\mathrm{H}(\delta 1.75), 29-\mathrm{H}_{3}(\delta 1.21)$ and $3-\mathrm{H}(\delta 3.54)$, and $28-\mathrm{H}_{3}(\delta 1.10)$ and $17 \alpha-\mathrm{H}(\delta 1.75)$.

Screening of the Antilipemic Effects of Acerinol (1c) ICR mice (10 per group), male, 6 weeks old, were used. Triton WR-1339 solution $(62.5 \mathrm{mg} / \mathrm{ml}$ of $0.15 \mathrm{M}-\mathrm{NaCl})$ was prepared, and $450 \mathrm{mg} / \mathrm{kg}$ was given i.v., then $0.25 \% \mathrm{CMC}$ suspension $(10 \mathrm{ml} / \mathrm{kg})$ was given p.o. and the same volume of the suspension was given after $20 \mathrm{~h}$. Blood $(0.5 \mathrm{ml})$ was taken $23 \mathrm{~h}$ later, and after the usual treatment, the cholesterol and triglycerides content was measured by the members of the Research Center of Takeda Pharmaceutical Company. The results: control-body weight gain (BW-gain), $-7.4 \pm 0.5 \mathrm{~g}$; plasma triglycerides, $1980 \pm 1007 \mathrm{mg} / \mathrm{ml}$ (TG, $100 \%)$; plasma cholesterol, $560 \pm 180 \mathrm{mg} / \mathrm{ml}(\mathrm{CH}, 100 \%)$; clofibrate $(300 \mathrm{mg} / \mathrm{kg})-\mathrm{BW}$-gain, $-7.3 \pm 0.6 \mathrm{~g} ; \mathrm{TG}, 57 \% ; \mathrm{CH}, 77 \% ; 1 \mathrm{c}(100$ $\mathrm{mg} / \mathrm{kg})-\mathrm{BW}$-gain, $-7.8 \pm 1.1 \mathrm{~g} ; \mathrm{TG}, 1.4 \%$; CH, $31 \%$; $1 \mathrm{c}(300 \mathrm{mg} / \mathrm{kg})-$ BW-gain, $7.4 \pm 1.0 \mathrm{~g}$; TG, $1.5 \%$; $\mathrm{CH}, 37 \%$.

Acknowledgements The authors are grateful to Amano Pharmaceutical Company, Nagoya, for the generous gift of lactase F[Amano] and cellulase T[Amano]4. They are also grateful to Mr. K. Minoura for NMR spectra and Mrs. M. Fujitake for mass spectra at Osaka University of Pharmaceutical Sciences, and to Mr. H. Hayasaka and Mr. K. Ohba of the Faculty of Pharmaceutical Sciences, Tohoku University, for culturing Cimicifuga simplex. They are also thankful for the members of Takeda Research Center due to the bioassay.

\section{References and Notes}

1) Part XVIII: Kusano A., Shibano M., Kusano G., Chem. Pharm. Bull., 44, 167-172 (1996).

2) Sakurai N., Inoue T., Nagai M., Chem. Pharm. Bull., 27, 158-165 (1979).

3) Kusano G., Idoji M., Sogoho Y., Shibano M., Kusano A., Iwashita S., Chem. Pharm. Bull., 42, 1106-1110 (1994). Erratum: The chemical shifts of methoxy groups (in pyridine- $d_{5}$ ) are revised to 3.26 and $3.27 \mathrm{ppm}$ from 3.49 and $3.50 \mathrm{ppm}$ at Table 1 of p. 1107.

4) Kusano A., Shimizu K., Idoji M., Shibano S., Kusano G., Chem. Pharm. Bull., 43, 279-283 (1995).

5) Kusano G., Hojo Y., Kondo Y., Takemoto T., Chem. Pharm. Bull., 25, 3182-3189 (1977).

6) Li J. X., Kadota S., Hattori M., Yoshimati S., Shiro M., Ogawa N., Mizuno H., Namba T., Chem. Pharm. Bull., 41, 832-841 (1993).

7) Kusano G., Uchida H., Murakami Y., Sakurai N., Takemoto T., Yakugaku Zasshi, 96, 321-325 (1976).

8) This compound was named isoacerinol in the 112th Annual Meeting of the Pharmaceutical Society of Japan, 1992, Abstract Papers, 159 (1992), but the name of 24-epi-acerinol is preferred and is used to avoid further confusion.

9) Dillon J., Nakanishi K., J. Am. Chem. Soc., 97, 5417-5422 (1975).

10) Kusano G., Takemoto T., Yakugaku Zasshi, 95, 1133-1137(1975). 
11) Takemoto T., Kusano G., Yakugaku Zasshi, 87, 1569-1572(1967).

12) Takemoto T., Kusano G., Yakugaku Zasshi, 88, 623-626 (1968).

13) Takemoto T., Kusano G., Yakugaku Zasshi, 89, 954-958 (1969).

14) Kusano A., Shibano S., Kitagawa S., Kusano G., Nozoe S., Fushiya S., Chem. Pharm. Bull., 42, 1940-1943 (1994).

15) Kusano A., Shibano M., Kusano G., Chem. Pharm. Bull., 43,
$1167-1170$ (1995).

16) Dr. Suzuoki J. of the Takeda Pharmaceutical Company: Private note.

17) D-Galactose and D-glucose were identified by Prof. Shigenobu Arihara of Tokushima Bunri University, for whom the authors are very grateful. 